\title{
Weed Management in Autumn Fresh Market Spinach: A Nonchemical Alternative
}

\author{
Marco Fontanelli ${ }^{1,3}$, Luisa Martelloni ${ }^{2}$, Michele Raffaelli ${ }^{1}$, \\ Christian Frasconi ${ }^{1}$, Marco Ginanni $^{2}$, and Andrea Peruzzi ${ }^{1}$
}

\begin{abstract}
ADDITIONAL INDEX WORDS. agricultural engineering, flaming, integrated organic farming system, mechanical thermal weeding, Spinacia olevacea, stale seedbed technique

Summary. Physical rather than chemical treatments are preferred for integrated production and are required for organic production to ensure a sustainable production. Weed management in many horticultural crops is heavily constrained by the limited number of herbicides available. Physical weed control strategies, on the other hand, are essential to organic vegetable production and greatly assist conventional vegetable farmers. A physical weed control strategy was developed and compared with a standard chemical strategy within an integrated farming system in fresh market spinach (Spinacia olevacea). The experiment was conducted on a farm in the Serchio Valley (Tuscany, central Italy) in 2004 and 2005, where spinach is one of the most important crops. The physical weed control strategy consisted of a stale seedbed technique and postemergence treatments using various mechanical and thermal machines. The chemical weed control strategy consisted of a single postemergence herbicide treatment using phenmedipham at $\mathbf{1 5 . 8 \%}$ in compliance with integrated production norms in Italy. Strategy performance was assessed in terms of weed density and biomass, total labor requirement, and crop yield. Compared with the chemical system, the physical system required a substantially larger labor input (19vs. $6 \mathrm{~h} \cdot \mathrm{ha}^{-1}$ ), but like the chemical system, did not require hand weeding. In addition, the physical system reduced weed dry biomass at harvest by $50 \%$ and increased spinach fresh yield by $35 \%$. Physical strategies therefore are a valid alternative to the use of herbicides in fresh market spinach and may be especially desirable given the increasing importance of nonchemical weed control in integrated, organic, and conventional farming systems in Europe and the United States.
\end{abstract}

S pinach is a quick-maturing, coolseason vegetable crop grown for both fresh and processing markets. Italy is Europe's leading spinach producer with $\approx 7000$ ha (Food and Agriculture Organization of the United Nations, 2013) and Tuscany is the top region in Italy for spinach production - the coastal area being particularly suitable for this crop. The total harvested area of spinach in Tuscany is $\approx 1100$ ha annually, with a total production of $\approx 16,320 \mathrm{Mg}$ (Regione Toscana, 2015). Spinach is grown in central Italy from September

We wish to express our thanks to the Municipalities of San Giuliano Terme and Vecchiano, Pisa, Italy, for funding this research; to Roberta Del Sarto and Calogero Plaia of Department of Agriculture, Food and Environment; and Paolo Gronchi and Alessandro Pannocchia of Centro di Ricerche AgroAmbientali "Enrico Avanzi" (CiRAA) for their valuable contributions.

${ }^{1}$ Department of Agriculture, Food and Environment, University of Pisa, Via del Borghetto, 80, 56124 Pisa, Italy

${ }^{2}$ Centro di Ricerche Agro-Ambientali "Enrico Avanzi" (CiRAA), University of Pisa, Via Vecchia di Marina 6, 56122 S. Piero a Grado, Pisa, Italy

${ }^{3}$ Corresponding author. E-mail: marco.fontanelli@ unipi.it. to May. When sown in September and at the end of winter, the crop cycle is very short $(60 \mathrm{~d})$, whereas the crop cycle is longer when spinach is sown in winter.

Weed control in spinach, as in many other specialty horticultural crops, is a major problem and is strongly affected by the limited number of herbicides available (Bàrberi, 2002; Fennimore and Doohan, 2008). Most spinach crops thus require hand weeding to produce satisfactory yields. In addition, production norms must be taken into account when farmers want to join integrated production programs or organic farming systems. Recent European Union guidelines promote limited or reduced pesticide use and recommend using physical/ nonchemical alternatives (European Union, 2009a). Sustainable farming management practices are also very important in terms of the crosscompliance direct support mechanism of the Common Agricultural Policy (European Union, 2009b, 2009c).

Physical weed control in spinach is especially challenging because there is a low tolerance for weed contamination in the marketed crop (Smith et al., 2009). Another challenge with fresh market spinach production is that leaves must not be damaged during weeding operations to avoid compromising its commercial quality.

Mechanical weed control is widely used for both presowing and postemergence weed management. Thermal weed control is increasingly used in both preemergence of the crop (stale seedbed technique) and postemergence in heat-tolerant crops [e.g., maize (Zea mays), onion (Allium cepa), and garlic (Allium sativum)]. The stale seedbed technique can be an effective weed control measure because it depletes the weed seed bank, which interferes with the crop during the growing season (Forcella et al., 1993).

Physical weed control has been tested with good results on many spring-summer crops (Leblanc et al., 2006; Rasmussen et al., 2004; Ulloa et al., 2011), winter cereals (Jensen et al., 2004; Pardo et al., 2008; Rasmussen et al., 2009), and horticultural crops (Ascard and Fogelberg, 2008; Riemens et al., 2007; van der Weide

\begin{tabular}{llll}
\hline $\begin{array}{l}\text { Units } \\
\text { To convert U.S. to SI, } \\
\text { multiply by }\end{array}$ & U.S. unit & SI unit & $\begin{array}{l}\text { To convert SI to U.S., } \\
\text { multiply by }\end{array}$ \\
\hline 0.4047 & $\mathrm{acre}(\mathrm{s})$ & $\mathrm{ha}$ & 2.4711 \\
0.1 & $\mathrm{bar}$ & $\mathrm{MPa}$ & 10 \\
0.3048 & $\mathrm{ft}$ & $\mathrm{m}$ & 3.2808 \\
0.0929 & $\mathrm{ft}^{2}$ & $\mathrm{~m}^{2}$ & 10.7639 \\
9.3540 & $\mathrm{gal} / \mathrm{acre}$ & $\mathrm{L} \cdot \mathrm{ha}^{-1}$ & 0.1069 \\
2.54 & inch $(\mathrm{es})$ & $\mathrm{cm}$ & 0.3937 \\
25.4 & inch $(\mathrm{es})$ & $\mathrm{mm}$ & 0.0394 \\
1.1209 & $\mathrm{lb} / \mathrm{acre}$ & $\mathrm{kg} \cdot \mathrm{ha}^{-1}$ & 0.8922 \\
1.6093 & $\mathrm{mph}$ & $\mathrm{km} \cdot \mathrm{h}^{-1}$ & 0.6214 \\
305.1517 & $\mathrm{oz} / \mathrm{ft}^{2}$ & $\mathrm{~g} \cdot \mathrm{m}^{-2}$ & 0.0033 \\
0.9072 & ton $(\mathrm{s})$ & $\mathrm{Mg}$ & 1.1023 \\
2.2417 & ton $(\mathrm{s}) / \mathrm{acre}$ & $\mathrm{Mg} \cdot \mathrm{ha}^{-1}$ & 0.4461 \\
$\left({ }^{\circ} \mathrm{F}-32\right) \div 1.8$ & ${ }^{\circ} \mathrm{F}$ & ${ }^{\circ} \mathrm{C}$ & $\left({ }^{\circ} \mathrm{C} \times 1.8\right)+32$ \\
& & & \\
\end{tabular}


et al., 2008). Cultivation remains a critically important component in organic farming systems. A stirrup and block cultivator was found to be more effective in pepper (Capsicum annumm) and broccoli (Brassica oleracea var. italica) than a conventional S-tine cultivator (Evans et al., 2012). Mechanical and thermal methods, while less effective than herbicides in processing spinach, did not negatively affect yield (Tei et al., 2002). In particular, split-hoeing and finger weeding showed a high potential in direct mechanical weed control in spinach, leading to an $80 \%$ reduction in average weed biomass at harvest. Finger weeders have been imported from the United States and operate from the sides of the crop row and beneath the crop leaves (van der Weide et al., 2008). In addition, advanced technology machines for physical weed control, which use a precision vision guidance system, can be used for within-row mechanical weed removal in vegetables (Fennimore et al., 2014). Soil steaming also represents an interesting physical method to reduce weed emergence and plant disease in vegetable and flower production, and a possible alternative to chemical soil fumigation (Rainbolt et al., 2013).

In this study, a physical weed control strategy, suitable for fresh market spinach grown on raised beds, was compared with a chemical weed control strategy. The objective was to develop a new strategy for integrated weed management, which could be used in organic farming systems.

\section{Materials and methods}

On-farm weed control trials involving weed control in spinach grown in the Serchio Valley were conducted in 2004 and 2005 on a farm located in Vecchiano, in the province of Pisa, Italy (lat. $43^{\circ} 46^{\prime} 56.52^{\prime \prime} \mathrm{N}$, long. $\left.10^{\circ} 21^{\prime} 22.03^{\prime \prime} \mathrm{E}\right)$, on sandy-silty soil (55\% sand, $35 \%$ silt, $10 \%$ clay, $2 \%$ organic matter). The experiment compared chemical and physical weed control strategies within an integrated production farming system.

Spinach in both chemical and physical weed control systems was sown on raised beds, as is typical for fresh market spinach in the area. Raised beds are especially important for autumn sowings, when waterlogging may damage the crop. Raised beds were $20 \mathrm{~cm}$ in height and $1.4 \mathrm{~m}$ wide with $40 \mathrm{~cm}$ spacing between beds (Fig. 1).
Crop fertility needs were provided by a preplant application and incorporation of $350 \mathrm{~kg} \cdot \mathrm{ha}^{-1}$ of $12 \mathrm{~N}-4.4 \mathrm{P}-$ 16.6K (Nitrophoska Elite; EuroChem Agro, Cesano Maderno MB, Italy).

The fresh market 'Springer' spinach was sown in all plots during autumn. In the raised beds where a chemical weed control was applied, sowing was performed in the traditional manner using a seed drill at a seeding rate of 580,000 seeds/ha with eight rows per bed $(\approx 10 \mathrm{~cm}$ within-row and $12.5 \mathrm{~cm}$ betweenrow spacing). For the physical weed control treatment, sowing was performed using a precision planter at the same seeding rate but with five rows per bed ( $\approx 6 \mathrm{~cm}$ within-row and $20 \mathrm{~cm}$ between-row spacing). The between-row space was widened to allow for postemergence hoeing. Spinach was manually harvested following the normal practice in the Serchio Valley. Normally, hand harvesting is carried out on several different dates to obtain the appropriate size of fresh market spinach. Figure 2 shows the total seasonal (October to December) rainfall and temperature followed by the long-term average of the area during 2004 and 2005.

\section{Weed management techniques and operating equipment}

The chemical weed control strategy was carried out using a single postemergence herbicide treatment using phenmedipham at $\mathbf{1 5 . 8 \%}$ (Betanal; Bayer CropScience, Monheim am Rhein, Germany), according to the operative conditions and the norms for integrated production in Italy. The herbicide was sprayed using a flat, antidrift spray nozzle (110015; TeeJet Technologies, Springfield, IL) at 0.2 $\mathrm{MPa}$ in solution at $400 \mathrm{~L} \cdot \mathrm{ha}^{-1}$ using a boom-mounted sprayer (Oktopus Boom Nobili, Bologna, Italy). The weed growth stage varied from the cotyledonary to two- to four-leaf stage, while spinach was about at four leaves.

The physical weed control strategy used a stale seedbed technique and postemergence cultivation (American Society of Agricultural Engineers, 2004). The treatment timing depended on both weed and crop stages. The stale seedbed technique was performed using two treatments with a rolling harrow, $\approx 10 \mathrm{~d}$ apart, and flaming before crop emergence.

Postemergence cultivation weed control treatments were carried out using a rolling harrow hoe in the between-rows and a precision hoe in both between- and within-rows. The time sequence of physical weed control strategy is reported in Table 1 . The machines used for the physical weed control were designed and built at the University of Pisa.

The rolling harrow was used in the stale seedbed technique (Fig. 3) and for treatments after crop emergence (rolling harrow hoe conformed) (Fig. 4) (Raffaelli et al., $2010,2011)$. The machine is equipped with spike disks (front) and cage rolls (rear). The rolling harrow eliminates the weeds through the passage of spike discs that till the soil at a depth of 3 to $4 \mathrm{~cm}$, followed by the cage rolls that work at a high peripheral speed and till the soil at a depth of 1 to $2 \mathrm{~cm}$. Discs and rolls are placed close together when the rolling harrow is used to prepare the

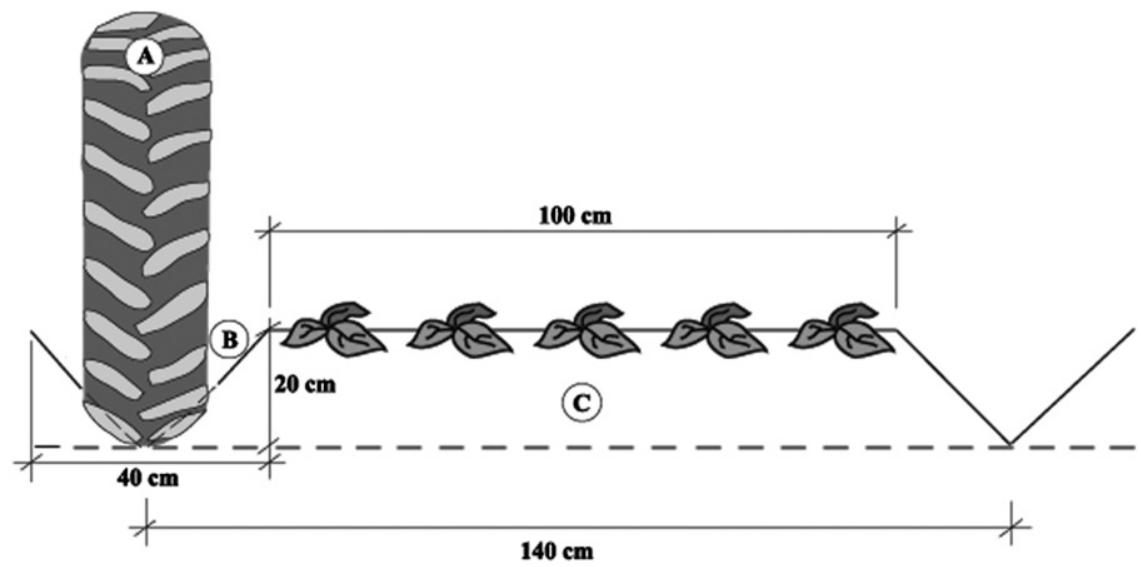

Fig. 1. Raised beds in spinach crops cultivated in the Serchio Valley, Italy: (A) wheel tractor, (B) traffic lane, and (C) raised bed; $1 \mathrm{~cm}=0.3937$ inch. 

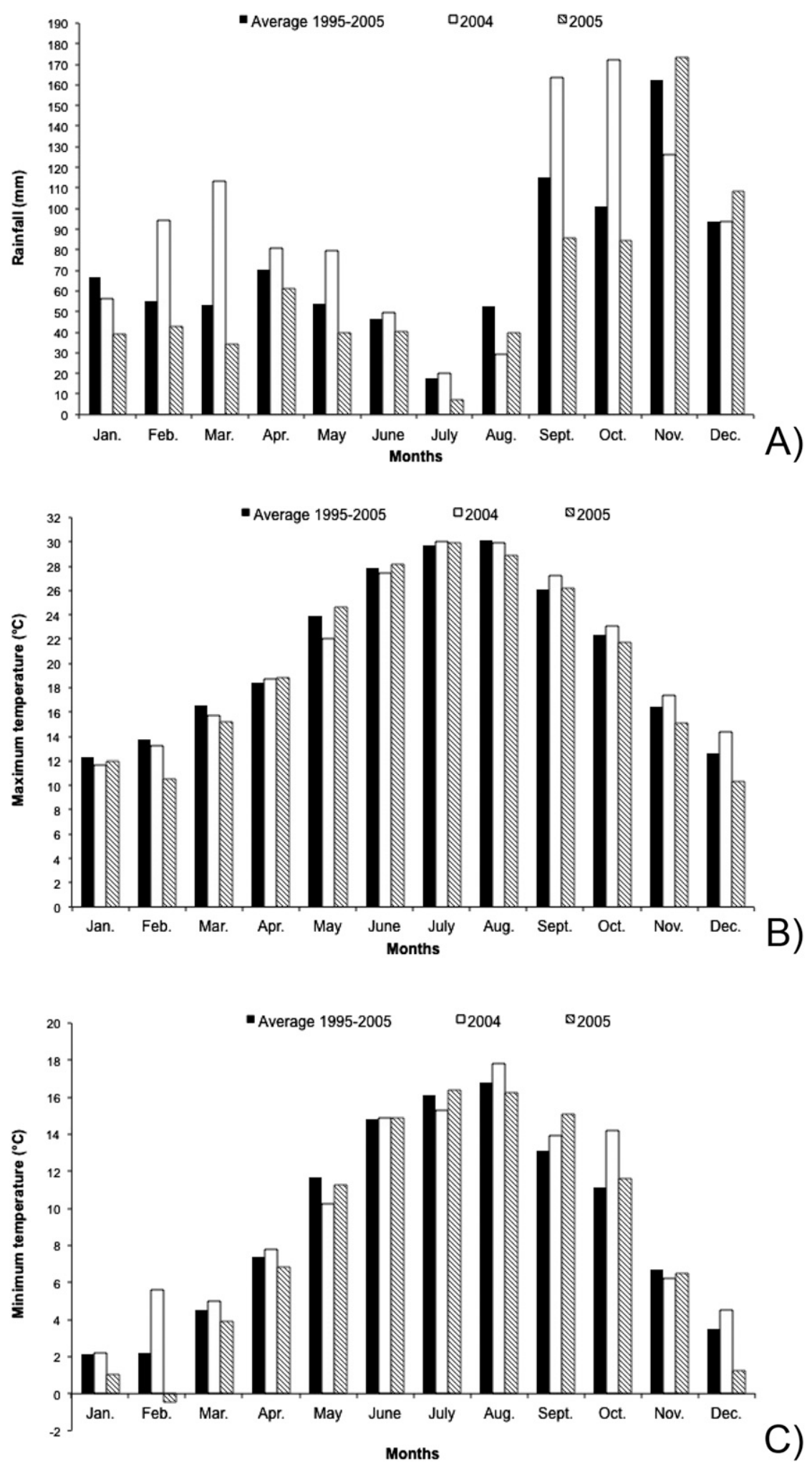

Fig. 2. Climatic data recorded in Vecchiano (Pisa, Italy) in 2004-05 and 11-year (1995-2005) averages: (A) total monthly rainfall values, (B) average monthly maximum temperature values, and $(C)$ average monthly minimum temperature values; $1 \mathrm{~mm}=0.0394$ inch, $\left(1.8 \times{ }^{\circ} \mathrm{C}\right)+32={ }^{\circ} \mathrm{F}$.

seedbed and to achieve a nonselective mechanical weed control in the stale seedbed technique (rolling harrow). Discs and rolls are spaced when the rolling harrow is used for selective postemergence precision betweenrow weeding (hoe-conformed rolling harrow).
The precision hoe (like a small cultivator) was used for selective weeding in late spinach postemergence (Fig. 5) (Raffaelli et al., 2010). This machine can perform "precision weeding" because it is equipped with a manual guidance system. One operator drives the tractor and a backseat operator can adjust the position of the working tools using a steering handle to avoid crop damage. The machine is built on a square tool bar bearing working tools and attached to the tractor three-point hitch. In this experiment, the tools were placed on six articulated parallelograms. Each parallelogram was equipped with two different tools: rigid elements and torsion weeders for between-row and in-row weeding, respectively.

The rigid elements have a $9-\mathrm{cm}$ wide horizontal blade designed to cut the weeds between the crop rows, working like a small cultivator. The torsion weeders are elastic tines (a couple per crop row) for selective weed control in the crop rows. Selectivity is determined by the difference in anchorage and development existing between crop and weeds. The torsion weeders work in a horizontal position as follows: a torsion spring enables the tines to flex when they meet a fairly developed plant (generally a crop plant but it could also be a large weed) that puts up resistance to the machine. Thus, small weeds can be uprooted, buried, or removed from the in-row space without damaging the crop. The position of torsion weeders can be modified according to the level of aggressiveness required. Treatment becomes more intense when the tines are positioned close to the row crop. The hand guidance system could be replaced in the future by less labor-intensive guidance systems based on electronic, optical, or hydraulic applications, thus obviating the need for a backseat operator.

The flaming machine was equipped with five $25-\mathrm{cm}$-wide rod burners and three liquefied petroleum gas (LPG) tanks (Fig. 6) (Raffaelli et al., 2010,2011). The burners generate an open flame, which gives a thermal shock to the plant tissue. The machine was used before crop emergence.

\section{Experimental assessments}

MACHINE AND YARD OPERATIONAL CHARACTERISTICS. All the main operational characteristics concerning the 
Table 1. Time sequence of the physical weed control treatments carried out in fresh market spinach in Pisa, Italy.

\begin{tabular}{|c|c|c|c|c|}
\hline \multirow[b]{3}{*}{ Treatments } & \multicolumn{4}{|c|}{ Timing (d) } \\
\hline & \multicolumn{2}{|c|}{2004} & \multicolumn{2}{|c|}{2005} \\
\hline & $\overline{\text { DBS }}$ & DAS & $\overline{\mathrm{DBS}}$ & $\overline{\text { DAS }}$ \\
\hline First rolling harrowing & 13 & & 6 & \\
\hline Second rolling harrowing & 1 & & 0 & \\
\hline Flame weeding & & 5 & & 6 \\
\hline Rolling harrowing hoe conformed & & 20 & & 25 \\
\hline Precision hoeing & & 34 & & 35 \\
\hline
\end{tabular}

DBS = days before sowing; DAS = days after sowing.

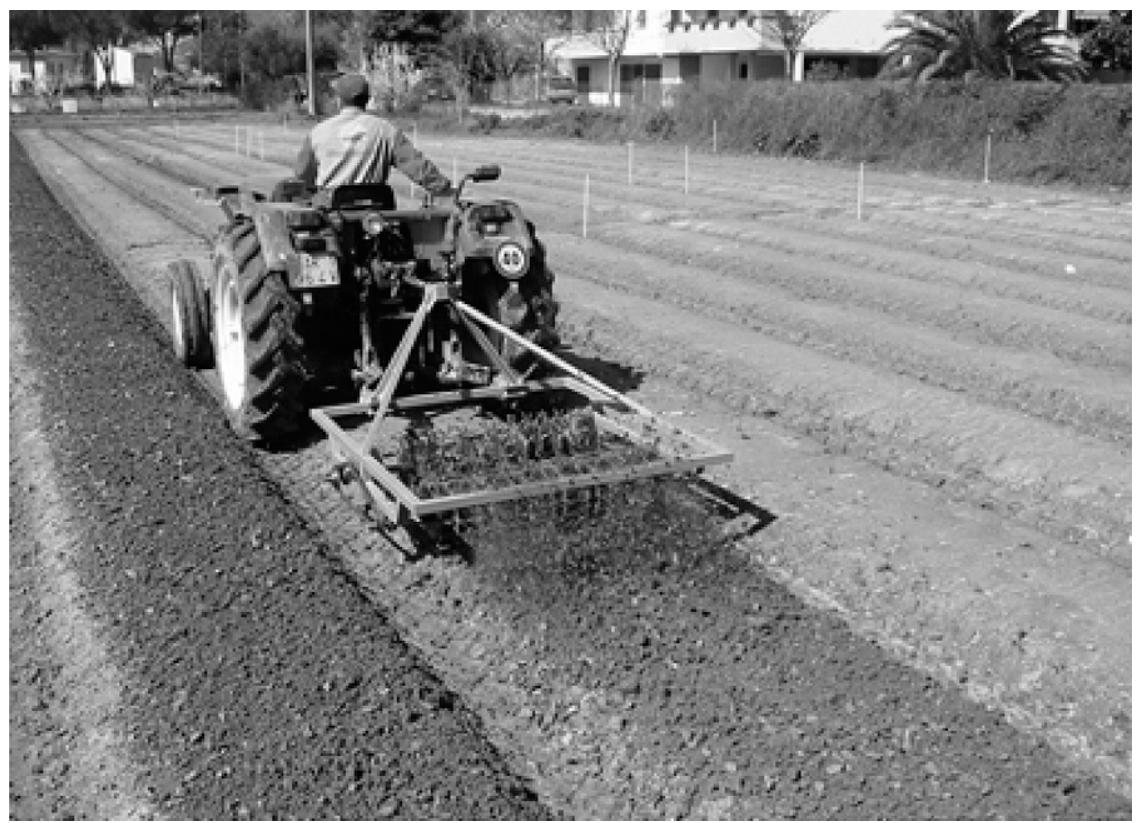

Fig. 3. Rolling harrow used during a presowing weed control treatment on spinach within the stale seedbed technique.

weed management for both systems were recorded. These included tillage depth, operating speed, working productivity, operating time, and fuel and LPG consumption for all the equipment used.

WeEDs. Weed density was evaluated immediately before ( 0 to 1 ) and 7 to $10 \mathrm{~d}$ after each weed control technique was used. All weeds growing within three randomly placed $0.25 \times 0.30-\mathrm{m}$ quadrants in each $1.40 \times 40-\mathrm{m}$ main plot were counted and recorded by species. At harvest, weeds were collected from two $1.40 \times 0.50-\mathrm{m}$ plots. The two subplots, used for weed biomass sampling, were randomly chosen from the four subplots from which spinach was harvested when it was considered harvest mature. The weeds in these subplots were clipped and then oven dried at $80^{\circ} \mathrm{C}$ until constant weight to assess dry biomass.
Crop YIELD. Spinach samples were harvested from four $1.40 \times$ $0.50-\mathrm{m}$ plots by cutting plants at the soil surface, removing any nonvaluable leaves as well as the remaining weeds, and finally by bundling the plants for transportation. Spinach fresh yield was determined to evaluate the marketable yield.

\section{Experimental, sample design and statistical analysis}

The experiment was arranged in a randomized complete block design with four replications. Combined and conventional analyses of variance (ANOVA) were carried out using the GLM function in SPSS Statistics (release 20.0.0; IBM, Armonk, NY) and CoStat (CoHort Software, Monterey, CA) on weed dry biomass and crop fresh yield, respectively. Treatment means were compared by a Fisher's protected least significant difference test at $P \leq 0.05$. The combined ANOVA was applied according to the Gomez and Gomez (1984) procedure to test the treatment by year interaction.

\section{Results}

PERFORMANCE OF THE MACHINES. The performance characteristics of the machines used in the trial are shown in Table 2 . The rolling harrow was used in the stale seedbed technique at a depth of $\approx 3 \mathrm{~cm}$ and consumed roughly $4 \mathrm{~kg} \cdot \mathrm{ha}^{-1}$ fuel. A relatively high speed $\left(\approx 6 \mathrm{~km} \cdot \mathrm{h}^{-1}\right)$ minimized the working time $\left(\approx 1.3 \mathrm{~h} \cdot \mathrm{ha}^{-1}\right)$; the working capacity was on average $0.77 \mathrm{ha} \cdot \mathrm{h}^{-1}$. Flaming was performed at a speed of $3.7 \mathrm{~km} \cdot \mathrm{h}^{-1}$ (working capacity and working time 0.44 and $2.26 \mathrm{~h} \cdot \mathrm{ha}^{-1}$, respectively) and LPG pressure of 0.2 $\mathrm{MPa}$, with an LPG consumption of roughly $20 \mathrm{~kg} \cdot \mathrm{ha}^{-1}$.

In postemergence use, the rolling harrow (hoe conformed) performed a very shallow soil tillage at a ground speed of $\approx 2 \mathrm{~km} \cdot \mathrm{h}^{-1}$. A slower operational speed for the rolling harrow treatment when used postemergence was necessary to avoid mechanical injury to the spinach plants. The low speed was necessary because tilling the soil around the spinach crop requires particular attention. Consequently, the working capacity was low $(0.25$ $\left.\mathrm{ha} \cdot \mathrm{h}^{-1}\right)$ and fuel consumption was roughly $11.8 \mathrm{~kg} \cdot \mathrm{ha}^{-1}$. The working speed of the precision hoe was 1.6 $\mathrm{km} \cdot \mathrm{h}^{-1}$, which was slower than the rolling harrow to lessen the potential for crop damage. This treatment caused very little soil disturbance because of its shallow working depth, which may have reduced the amount of weed seeds brought to the soil surface to germinate later in the season. Table 2 shows the total operating time for the two weed management systems. Total labor time averaged $\approx 19 \mathrm{~h} \cdot \mathrm{ha}^{-1}$ per year for the physical weed control program compared with $6 \mathrm{~h} \cdot \mathrm{ha}^{-1}$ per year for the chemical control strategy (Table 2).

WEED CONTROL AND YIELD. The initial composition of weed flora in 2 years and for the two weed management systems was characterized by redroot pigweed [Amaranthus retroflexus $(79 \%)$, common purslane [Portulaca oleracea $(5 \%)]$, black nightshade [Solanum nigrum (2\%)], lamb's quarters [Chenopodium album (1\%)], other dicotyledonous weeds (5\%) and grass weeds $(8 \%)$, represented mainly by kentucky bluegrass (Poa pratensis). In 


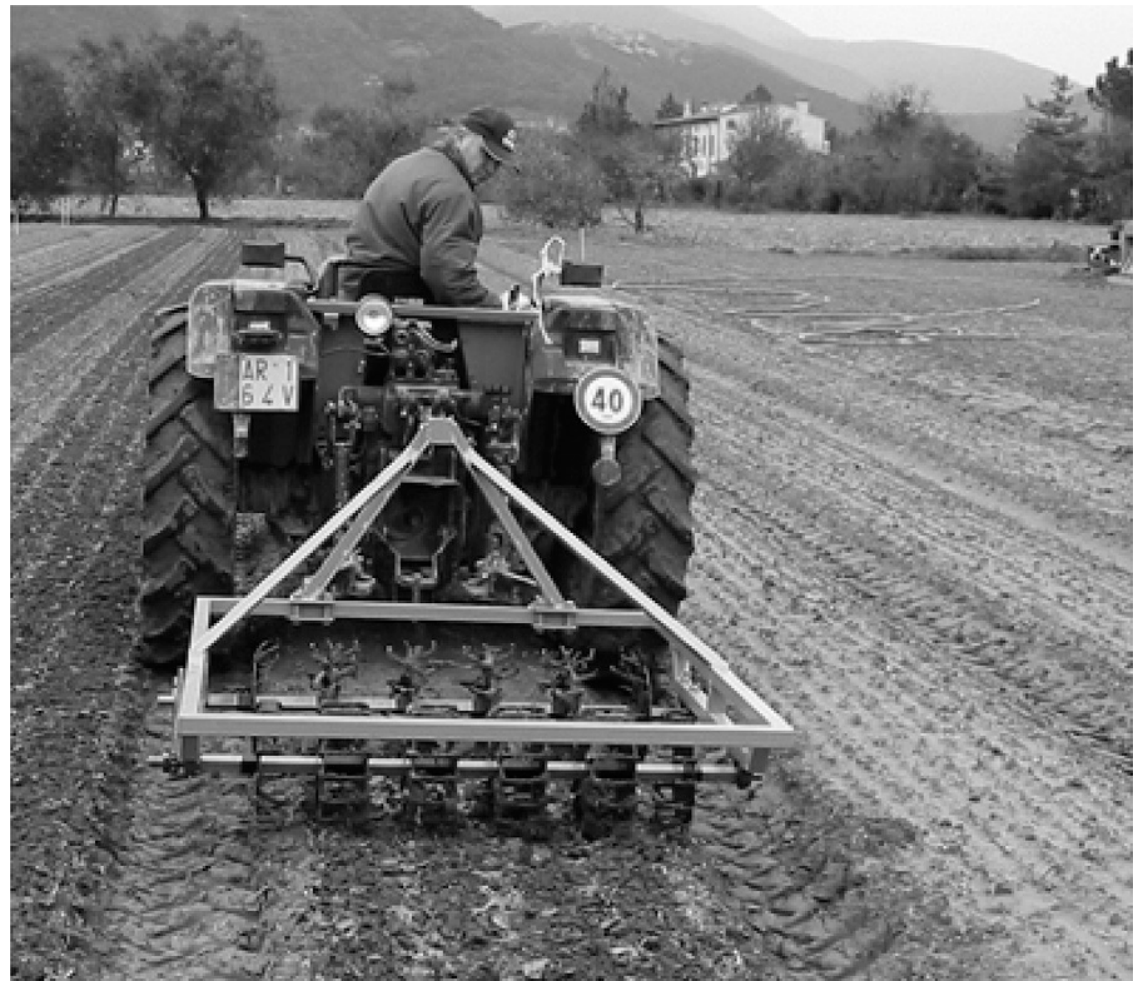

Fig. 4. Rolling harrow used for early postemergence between-row weed control treatment on spinach.

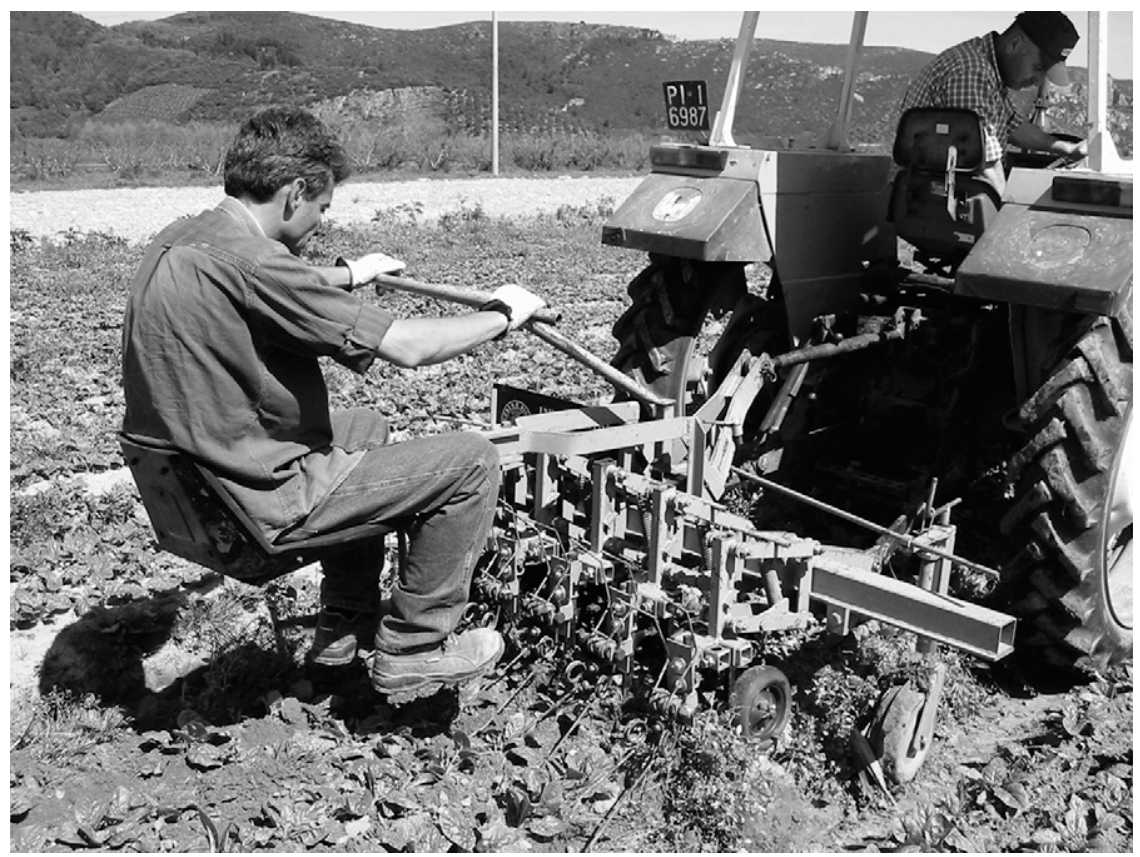

Fig. 5. Precision cultivating tillage treatment performed on spinach. The precision hoe was equipped with torsion weeders to control weeds in the within-rows.

2004, weed density was over 100 plants $/ \mathrm{m}^{2}$ before the first treatment with the rolling harrow, and $\approx 200$ plants $/ \mathrm{m}^{2}$ before the second. In 2005 , weed density was $\approx 270$ plants $/ \mathrm{m}^{2}$ before the first rolling harrow and $\approx 120$ plants $/ \mathrm{m}^{2}$ before the second.
In 2 years, the treatments with the rolling harrow were performed before crop seeding and reduced the numbers of emerging weeds by $100 \%$. Before crop emergence and flaming, weed density was 188 plants $/ \mathrm{m}^{2}$ in 2004 and 106 plants $/ \mathrm{m}^{2}$ in 2005 .
As with the rolling harrow, the flaming machine achieved a $100 \%$ "instantaneous" weed control, after seeding and before spinach emergence (Table 3 ).

The average composition of weed flora in 2 years in the physical weed management system before postemergence treatment was characterized by grass weeds $(55 \%)$, common purslane (21\%), knotweeds [Polygonum sp. (7\%)], redroot pigweed $(6 \%)$, shepherd's-purse [Capsella bursa-pastoris (5\%)], fieldspeedwell [Veronica persica (3\%)], and lamb's quarters $(3 \%)$.

In 2004, weed densities were 354 and 24 plants $/ \mathrm{m}^{2}$ before and after hoeing with the hoe conformed rolling harrow, whereas in 2005, weed densities were 361 and 37 plants $/ \mathrm{m}^{2}$, respectively. This treatment therefore reduced weeds by $93 \%$ in 2004 and $90 \%$ in 2005 . Weed density before the precision hoeing was 201 plants $/ \mathrm{m}^{2}$ in 2004 and 232 plants $/ \mathrm{m}^{2}$ in 2005 . The treatment reduced weed density by $81 \%$ and $82 \%$, respectively, in 2004 and 2005 , leaving 39 and 41 plants $/ \mathrm{m}^{2}$ on the ground (Table 3 ).

Weed density was measured before and after each physical weed control treatment (Table 3 ). This highlights the performance of both strategies, which were able to provide weed control without hand weeding.

Since treatment by year interaction was not significant for weed biomass at harvest, these data were pooled before analysis. Weed dry biomass at harvest was $\approx 2$-fold larger for the chemical weed control management system than the physical one $\left(\approx 70\right.$ vs. $\left.30 \mathrm{~g} \cdot \mathrm{m}^{-2}\right)$ (Table 4$)$. This is probably because the herbicide was only sprayed once, at the beginning of the crop cycle, in compliance with norms in Tuscany. The chemical treatment was effective enough to avoid hand weeding; however, repeated physical treatments achieved better results in terms of weed biomass reduction.

There was a significant treatment by year interaction for fresh spinach yield, thus data were analyzed separately by year. Fresh yield was $8.5 \mathrm{Mg} \cdot \mathrm{ha}^{-1}$ in 2004 and 8.9 $\mathrm{Mg} \cdot \mathrm{ha}^{-1}$ in 2005 for the physical weed management system, on average $35 \%$ larger than the values obtained by the chemical weed management system (Table 4). 


\section{Discussion}

Machinery used for the physical weed control was successful in controlling weeds in the spinach crop grown on raised beds from September to May when rainfall is likely to occur, both in the presowing/ emergence phase and in postemergence, when mechanical weeding is difficult because of the presence of the crop. The physical weed control avoided the need for hand weeding, which represents the main production

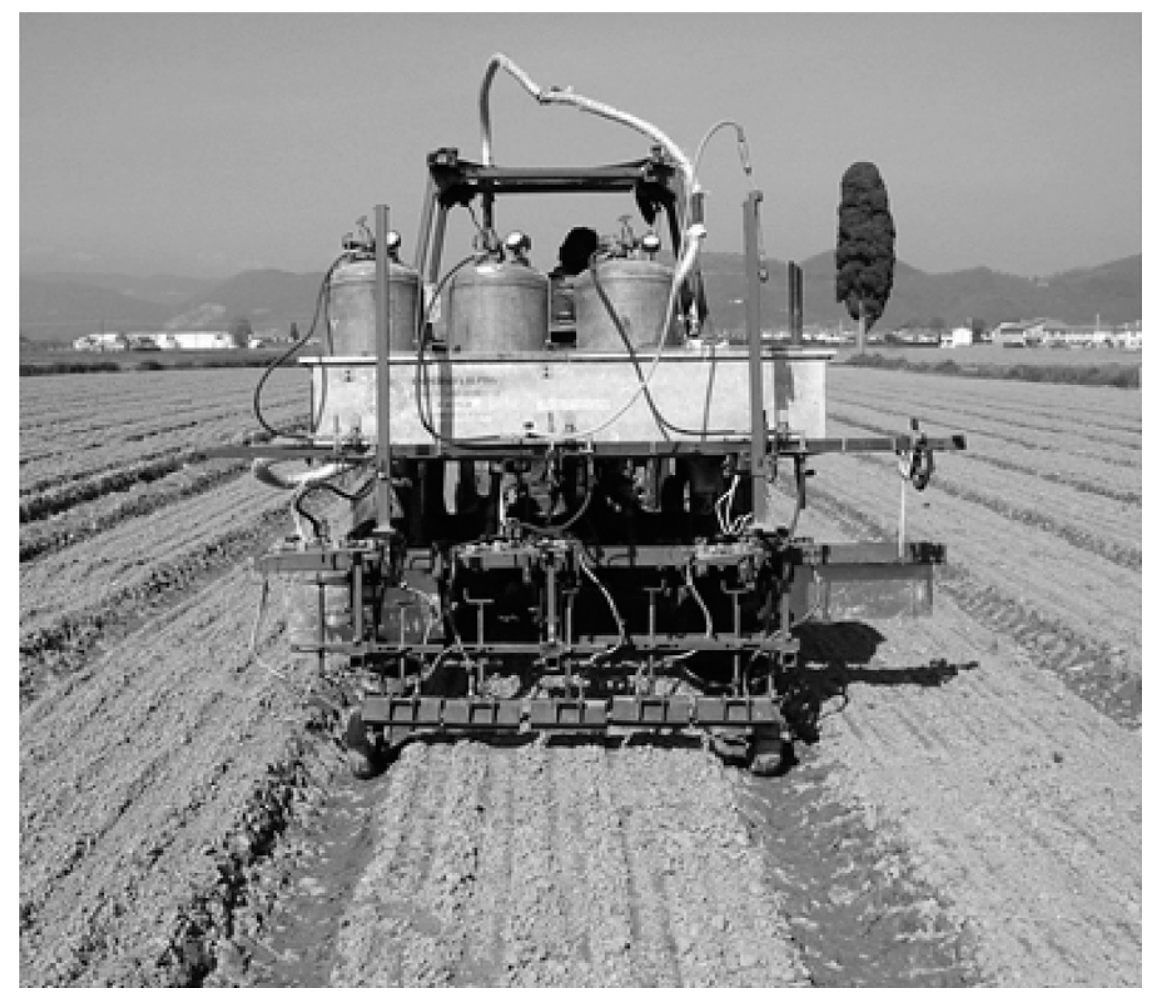

Fig. 6. Flaming machine performing a preemergence treatment on spinach in the stale seedbed technique. cost for farmers who aim to stop using herbicides. This was probably achieved because fresh market spinach is a fallwinter crop (winter weeds are usually less aggressive in this area because most are small graminaceaous species). Spinach has a short crop cycle $(60 \mathrm{~d})$ and the weed threshold is higher than in processing spinach because the harvest is manual (weeds interfere with the harvester machine).

Mechanical and thermal means were combined in a growth manage- ment system which integrated the stale seedbed technique. A modified spatial disposition of the crop enabled our machines to be used for postemergence weed control. This "holistic" approach to weed management reduced the weed dry biomass at harvest by $43 \%$ to $50 \%$ compared with the use of herbicides in the integrated production.

The sequence of treatments used in the stale seedbed controlled both broadleaves and grass weeds, and achieved a $100 \%$ weed control at the time of spinach seed sowing. Other authors reported weed control levels of $70 \%$ to $97 \%$ after weeding stale seedbeds with rotary hoes (Boyd et al., 2006; Buhler et al., 1992). Despite this, graminaceous species (Gramineae) were the dominant weeds before postemergence hoeing, which are more difficult to manage with mechanical means than broadleaves (Caldwell and Mohler, 2001). A similar weed population composition was also observed in the herbicide system in our experiment.

Many weed species are also capable of extended flushes of emergence over several weeks (Forcella et al., 2000). This weed capacity explains the presence of common purslane, lamb's quarters, and redroot pigweed even after the instantaneous and total weed control performed by the stale seedbed technique. The stale seedbed therefore depleted the weed seed bank and gave a competitive advantage to the spinach crop. However, postemergence weed control was needed to control weeds that had not germinated or emerged at the preplant weeding of the stale seedbed. The postemergence physical treatments reduced weed density by $80 \%$.

Table 2. Performance of the machines used for physical weed control in the 2 years of experiments in spinach near Pisa, Italy (2004-05) and total labor requirements for two weed management systems.

\begin{tabular}{|c|c|c|c|c|}
\hline Timing & Preplanting & Preemergence & $\begin{array}{c}\text { Postemergence } \\
\end{array}$ & Postemergence \\
\hline Machine characteristics $^{\mathrm{z}}$ & $\overline{\text { Rolling harrow }}$ & Flamer & $\overline{\text { Hoe conformed rolling harrow }}$ & $\overline{\text { Precision hoe }}$ \\
\hline Working depth $(\mathrm{cm})$ & 3.2 & - & 2.6 & 1.8 \\
\hline Working width $(\mathrm{m})$ & 1.4 & 1.4 & 1.4 & 1.4 \\
\hline Working capacity $\left(\mathrm{ha} \cdot \mathrm{h}^{-1}\right)$ & 0.8 & 0.4 & 0.3 & 0.2 \\
\hline Working time $\left(\mathrm{h} \cdot \mathrm{ha}^{-1}\right)$ & 1.3 & 2.3 & 4.0 & 5.2 \\
\hline & & & 2004 & 2005 \\
\hline \multirow{2}{*}{\multicolumn{3}{|c|}{$\begin{array}{l}\text { Total labor for physical weed control }\left(h \cdot h a^{-1}\right) \\
\text { Total labor for chemical weed control }\left(h \cdot h a^{-1}\right)\end{array}$}} & 16.7 & 21.7 \\
\hline & & & 6.6 & 5.5 \\
\hline
\end{tabular}

${ }^{\mathrm{z}} \mathrm{l} \mathrm{cm}=0.3937 \mathrm{inch}, 1 \mathrm{~km} \cdot \mathrm{h}^{-1}=0.6214 \mathrm{mph}, \mathrm{l} \mathrm{m}=3.2808 \mathrm{ft}, \mathrm{l} \mathrm{ha}=2.471 \mathrm{l} \mathrm{acres}, \mathrm{l} \mathrm{h} \cdot \mathrm{ha}^{-1}=0.4047 \mathrm{~h} / \mathrm{acre}, \mathrm{l} \mathrm{kg} \cdot \mathrm{ha} \mathrm{a}^{-1}=0.8922 \mathrm{lb} / \mathrm{acre}$. 
Table 3. Weed density recorded immediately before and 7-10 d after each physical weed control treatments on spinach near Pisa, Italy (2004 and 2005).

\begin{tabular}{lccccc}
\hline & \multicolumn{3}{c}{ Weed density $\left(\text { plants } / \mathbf{m}^{2}\right)^{\mathbf{z}}$} \\
\cline { 2 - 3 } \cline { 5 - 6 } Treatments & \multicolumn{2}{c}{$\mathbf{2 0 0 4}$} & & \multicolumn{2}{c}{$\mathbf{2 0 0 5}$} \\
\cline { 2 - 3 } \cline { 5 - 6 } First rolling harrowing & Before & After & & Before & After \\
Second rolling harrowing & 203 & 0 & & 272 & 0 \\
Flame weeding & 188 & 0 & & 119 & 0 \\
Postemergence & & & & 361 & 0 \\
Rolling harrowing hoe conformed & 354 & 24 & & 361 \\
Precision hoeing & 201 & 39 & & 232 & 41 \\
\hline
\end{tabular}

${ }^{\mathrm{z}} 1$ plant $/ \mathrm{m}^{2}=0.0929 \mathrm{plant} / \mathrm{ft}^{2}$.

Table 4. Yield and weed dry biomass (2004-05) for the two different weed control strategies carried out on fresh market spinach near Pisa, Italy.

\begin{tabular}{lcccc}
\hline \multirow{2}{*}{$\begin{array}{l}\text { Weed management } \\
\text { system }\end{array}$} & \multicolumn{2}{c}{ Yield $\left(\mathbf{M g} \cdot \mathbf{h a}^{-\mathbf{1}}\right)^{\mathrm{z}}$} & & Weed dry biomass $\left(\mathbf{g} \cdot \mathbf{m}^{-\mathbf{2}}\right)^{\mathrm{z}}$ \\
\cline { 2 - 3 } & $\mathbf{2 0 0 4}$ & $\mathbf{2 0 0 5}$ & & Combined \\
\hline Physical & 8.50 & 8.93 & 33.34 \\
Chemical & 6.78 & 5.98 & 71.13 \\
SED $^{\mathrm{y}}$ & 0.157 & 0.201 & 5.802 \\
$t(\mathrm{df})^{\mathrm{x}}$ & $3.182(3)$ & $3.182(3)$ & $2.447(6)$ \\
LSD $^{\mathrm{w}}$ & 0.498 & 0.639 & 14.197 \\
\hline
\end{tabular}

${ }^{\mathrm{z}} \mathrm{l} \mathrm{Mg} \cdot \mathrm{ha}^{-1}=0.446 \mathrm{l}$ ton/acre, $\mathrm{lg} \cdot \mathrm{m}^{-2}=0.0033 \mathrm{oz} / \mathrm{ft}^{2}$.

$\mathrm{y}_{\mathrm{SE}}$ of the mean difference.

'Tabular value of Student's $t$-distribution and df.

"Fisher's least significant difference at $P \leq 0.05$.

For in-row postemergence mechanical weeding, the three most common tools are finger weeders, torsion weeders, and brush weeders (Ascard et al., 2014; Bowman, 1997; van der Weide et al., 2008). Many types of finger weeders are available on the market, are easy to adjust, and their action is gentle (Ascard et al., 2014). Finger weeders have been successfully tested in spinach by Tei et al. (2002), showing a high potential in direct weed control. We used torsion weeders rather than finger weeders to test a different in-row tool in spinach compared with the previous experiments carried out by Tei et al. (2002). Torsion weeders are the least expensive option and are very effective. Moreover, finger weeders are not suited to heavily crusted soil (Ascard et al., 2014; Bowman, 1997). Torsion weeders also have some constraints due to the need for an accurate steering system and adjustment to avoid crop damage (Ascard et al., 2014; Bowman, 1997). However, in our experiment, there were no significant crop injuries. Brush weeders were not taken into consideration because they are probably the most expensive option, are slow, and not very easy to adjust (Ascard et al., 2014).

High-tech machines for in-row mechanical weeding, combined with crop sensing, will probably become increasingly popular in the near future. Several examples are already available on the market (Ascard et al., 2014; van der Weide et al., 2008). The Robocrop (Garford Farm Machinery, Peterborough, England) in-row weeder uses a special shaped rotating disc to cultivate at a shallow depth within the crop row (Garford Farm Machinery, 2015). The Robovator (Poulsen Engineering, Hvalsø, Denmark) within-row hoer uses automatic split knife hoeing tools which move in and out of the crop rows around the crop plants (Poulsen Engineering, 2015). The same concept has been adopted in the Steketee IC [Machinefabriek Steketee, Haringvliet, the Netherlands (Machinefabriek Steketee, 2015)] and Remoweed [Ferrari Costruzioni Meccaniche, Guidizzolo, Italy (Ferrari Costruzioni Meccaniche, 2015)]. However, these machines are generally quite expensive and tend to be used for transplanted vegetables.

The larger spinach yield obtained with the physical weed control system tested in this trial reflected the effectiveness of the stale seedbed and postemergence mechanical treatments compared with a single postemergence herbicide application. In addition, using a hoe has well-known positive agronomic effects such as soil oxygenation and interruption of the capillary rise (Bàrberi, 2002). The different spatial arrangement of the cropping systems in the two weed management systems (five vs. eight seedlines per bed) probably did not greatly influence spinach yield in this trial as Tei et al., (2002) showed that betweenrow spacings of 12.5 and $25 \mathrm{~cm}$ did not modify spinach yield.

On the basis of the results achieved, physical weed control (mechanical and thermal means) would certainly benefit organic and integrated spinach growers. Mechanical weed control has always been considered as one of the principal alternatives for an integrated weed management system (Swanton and Weise, 1991). The physical strategy represents a good possible alternative to the use of herbicides in integrated, organic, and conventional agriculture. This is particularly relevant given the increasing emphasis put on nonchemical weed control methods in European legislation (European Union, 2009a) and the importance of the organic agriculture industry in the United States (Muramoto et al., 2013).

\section{Literature cited}

American Society of Agricultural Engineers. 2004. Terminology and definitions for agricultural tillage implements, p. 270-282. In: ASAE standards: ASAE S414. Amer. Soc. Agr. Eng., Madison, WI.

Ascard, J. and F. Fogelberg. 2008. Mechanical in-row weed control in transplanted and direct-sown bulb onions. Biol. Agr. Hort. 25:235-251.

Ascard, J., D. Hansson, and S.E. Svensson. 2014. Physical and cultural weed control in Scandinavia. Proc. 10th European Weed Res. Soc. Wkshp. Physical Cultural Weed Control. p. 2 (abstr.).

Bàrberi, P. 2002. Weed management in organic agriculture: Are we addressing the right issues? Weed Res. 42:176-193.

Bowman, G. 1997. Steel in the field: A farmer's guide to weed management tools, Handbook Series No. 2. Sustainable Agriculture Network, Beltsville, MD.

Boyd, N.S., E.B. Brennan, and S.A. Fennimore. 2006. Stale seedbed technique for organic vegetable production. Weed Technol. 20:1052-1057.

Buhler, D.D., J.L. Gunsolus, and D.F. Ralston. 1992. Integrated weed management techniques to reduce herbicide inputs in soybean. Agron. J. 84:973-978. 
Caldwell, B. and C.L. Mohler. 2001. Stale seedbed practices for vegetable production. HortScience 36:703-705.

European Union. 2009a. Directive $2009 / 128 / E C$. Official J. European Union 309:71-86.

European Union. 2009b. Council Regulation (EC) No. 1122/2009. Official J. European Union 316:65-112.

European Union. 2009c. Council Regulation (EC) No. 73/2009. Official J. European Union 30:16-99.

Evans, G.J., R.R. Bellinder, and R.R. Hahn. 2012. An evaluation of two novel cultivation tools. Weed Technol. 26:316-325.

Food and Agriculture Organization of the United Nations. 2013. Production, crops. 12 Jan. 2015. <http://faostat.fao. org/site/567/default.aspx\#ancor>.

Fennimore, S.A. and D.J. Doohan. 2008. The challenges of specialty crop weed control, future directions. Weed Technol. 22:176-188.

Fennimore, S.A., R.F. Smith, L. Tourte, M. Lestrange, and J.S. Rachuy. 2014. Evaluation and economics of a rotating cultivator in bok choy, celery, lettuce, and radicchio. Weed Technol. 28:364-372.

Ferrari Costruzioni Meccaniche. 2015. Automatic hoe - Remoweed. 12 Jan. 2015. <http://www.ferraricostruzioni.com/ en/news_tab/sarchiatrice_remoweed_2>.

Forcella, F., R.L. Benech-Arnold, R. Sanches, and C.M. Ghersa. 2000. Modelling seedling emergence. Field Crops Res. 67:123-139.

Forcella, F., K. Eradat-Oskoui, and S.W. Wagner. 1993. Application of weed seedbank ecology to low-input crop management. Ecol. Appl. 3:74-83.

Garford Farm Machinery. 2015. Robocrop inrow weeder. 12 Jan. 2015. <http://www. garford.com/products_robocropinrow. html>.
Gomez, K.A. and A.A. Gomez. 1984. Statistical procedures for agricultural research. 2nd ed. Wiley, New York, NY.

Jensen, R.K., J. Rasmussen, and B. Melander. 2004. Selectivity of weed harrowing in lupin. Weed Res. 44:245-253.

Leblanc, M.L., D.C. Cloutier, and K.A. Steward. 2006. Rotary hoe cultivation in sweet corn. HortTechnology 16:583-589.

Machinefabriek Steketee. 2015. Steketee. 12 Jan. 2015. <http://www.steketee. com/producten $>$.

Muramoto, J., S.R. Gliessman, C. Shennan, T. Pisani Gareau, K.L. Monsen, S. Pedersen, M.P. Bolda, O. Daugovish, C.T. Bull, C. Li, J. Leap, D. Nieto, J. Bryer, S.T. Koike, R.F. Smith, M. Gaskell, K.M. Klonsky, W. Salas, and G.J.M. Oomen. 2013. The organic research network project on the central coast of California. Acta Hort. 100:35-46.

Pardo, G., A. Cirujeda, J. Aibar, J. Cavero, and C. Zaragoza. 2008. Weed harrowing in winter cereal under semi-arid conditions. Span. J. Agr. Res. 6:661-670.

Poulsen Engineering. 2015. Mechanical hoeing robot. 12 Jan. 2015. <http:// www.visionweeding.com/Products/ Intra\%20Row\%20Weeding/ROBOVATOR. htm>.

Raffaelli, M., M. Fontanelli, C. Frasconi, M. Ginanni, and A. Peruzzi. 2010. Physical weed control in protected leaf-beet in central Italy. Renew. Agr. Food Syst. 25:8-15

Raffaelli, M., M. Fontanelli, C. Frasconi, F. Sorelli, M. Ginanni, and A. Peruzzi. 2011. Physical weed control in processing tomatoes in central Italy. Renew. Agr. Food Syst. 26:95-103.

Rainbolt, C.M., J.B. Samtani, S.A. Fennimore, C.A. Gilbert, K.V. Subbarao, J.S. Gerik, A. Shrestha, and B.D. Hanson. 2013. Steam as a preplant soil disinfestant tool in California cut-flower production. HortTechnology 23:207-214.

Rasmussen, J., J.I. Kurtzmann, and A. Jensen. 2004. Tolerance of competitive spring barley cultivars to weed harrowing. Weed Res. $44: 446-452$.

Rasmussen, J., H.H. Nielsen, and H. Gundersen. 2009. Tolerance and selectivity of cereal species and cultivars to postemergence weed harrowing. Weed Sci. $57: 338-345$.

Regione Toscana. 2015. Toscana in cifre, sistema statistico regionale - Agricoltura. 12 Jan. 2015. <http://ius.regione. toscana.it/cif/stat/index-agric.shtml>.

Riemens, M.M., R.Y. van der Weide, and H.W. Bleeker. 2007. Effect of stale seedbed preparations and subsequent weed control in lettuce (cv. Iceboll) on weed densities. Weed Res. 47:149-156.

Smith, R.F., S.A. Fennimore, and M. LeStrange. 2009. Spinach. Integrated weed management. 12 Jan. 2015. <http://www.ipm.ucdavis.edu/PMG/ r732700111.html>.

Swanton, C.J. and S.F. Weise. 1991. Integrated weed management: The rationale and approach. Weed Technol. 5:657-663.

Tei, F., F. Stagnari, and A. Granier. 2002. Preliminary results on physical weed control in processing spinach. Proc. 5th European Weed Res. Soc. Wkshp. Physical Weed Control. p. 164-171.

Ulloa, S.M., A. Datta, C. Bruening, B. Neilson, J. Miller, G. Gogos, and S.Z. Knezevic. 2011. Maize response to broadcast flaming at different growth stages: Effects on growth, yield and yield components. Eur. J. Agron. 34:10-19.

van der Weide, R.Y., P.O. Bleeker, V.T.J.M. Achten, L.A.P. Lotz, F. Fogelberg, and B. Melander. 2008. Innovation in mechanical weed control in crop rows. Weed Res. 48:215-224. 